\title{
The Influence of Income Shifting Incentives towards The Tax Haven Country Utilization: Case Study on the Companies listed in Indonesian Stock Exchange
}

\author{
Nurhidayati $^{*}$ and Hendyga Fuadillah ${ }^{2}$ \\ 1,2 Politeknik Keuangan Negara STAN \\ Jl. Bintaro Utama Sektor V Tangerang Selatan, INDONESIA \\ *Corresponding author; Email: nurhidayati@pknstan.ac.id
}

\begin{abstract}
This study aims to determine the association between a series of income shifting incentives, including multinationality, transfer pricing aggressiveness, thin capitalization, intangible assets, and tax haven country utilization. This study is based on a sample of 78 multinational companies listed on the Indonesia Stock Exchange over 2012-2016 period (390 firm-year). The results prove that, multinationality, thin capitalization, intangible asset are positively associated with tax haven utilization, while transfer pricing aggressiveness is not positively associated with tax haven utilization. Based on the additional analysis, basic and chemicals sectors have the highest association between a series of income shifting incentives and tax haven utilization among other industrial sectors and each industry sector has different ways of utilizing tax haven country. The findings of this study are expected to provide input to the Directorate General of Taxes the importance of reviewing debt to equity ratio rule which turned out to be one gap for the taxpayer and in making the proposed inspection plan and the potential thematic exploration related to profit shifting incentives more focused on basic industry and chemicals sector. The Directorate General of Taxes also needs to raise awareness of the taxpayers of agriculture, mining, basic and chemicals, and trade, service and investment, which has a growing number of subsidiaries in tax haven country. Increased supervision of intangible assets transfers in the agriculture and infrastructure, utilities \& transportation sectors also needs to be done.
\end{abstract}

Keywords: Income shifting; tax haven; multinationality; transfer pricing; thin capitalization; intangible assets.

\section{INTRODUCTION}

For a country, tax is an essential income for the country expenses. In the other hand, for the companies, tax is the extra charge that decrease the net income. Furthermore, in the economically speaking, the tax is the transfer of resources from the private sector to the public sector (Suandi, 2008). It is seen from how the reduction of tax revenue in a country might affect the whole income of the country, which will ultimately interfere the government's cycle activity as well as the economy. There is a statement from Cobham as has been quoted by Danny and [11] that sows that the tax revenue of the country may have so many leaking in several sides. Those sides might be from the multinational companies which have ability to obtain preferential tax treatment from developing countries, but then they transfer the income (income shifting), which should be taxable there, to another country (tax haven). This research is particularly to find out the indication of country revenue leak from the tax avoidance by exploiting the tax haven as the income shifting incentives. Tax avoidance is an arrangement of a transaction in order to obtain a tax advantage, benefit, or reduction in a manner unintended by the tax law" (Brown, 2012). In the several tax books, the term Tax Avoidance is usually identified as a transaction scheme which aims to minimize the tax burden by utilizing the loophole of regulations and the provision of taxation of a country. The Asprey Committee of Australia, as quoted by [76] states that in general the tax avoidance is the act which is still on the legal corridor but it is not based on "bonafide and adequate consideration", or against the intention of parliament.

According to Orlov, as quoted by Danny and [11] the tax avoidance in the international taxing is a common act with various ways or scheme and it is mostly done by the Multi National Corporation/ MNC in order to do the tax savings. The scheme tend to be like (1) transfer pricing, (2) thin capitalization, (3) treaty shopping, dan (4) controlled 
foreign corporation (CFC). Those four schemes involve some countries which are categorized as tax haven countries. The tax haven countries can be said as the countries which deliberately give the tax facilities to the taxpayers of another country to transfer their income to these tax haven countries so that the tax will be lower or even no tax at all. These companies who do the tax avoidance practices transfer their profit (transfer pricing) from Indonesia to other countries [2].

According to [56], the multinational company tends to transfer the profit to its affiliation company which operate in another countries because the tax are lower. The diversion might be in the various ways. It could be by deliberately do not repatriate the profit from the affiliates, or charge the administration, royalty, and the consultation service excessively, do the transfer pricing, or even thin capitalization through high interest loan to the affiliates.

Based on the theory of capital structure presented by [59], debt can be used to increase the value of the company, because there are tax incentives received by the company through the ability of interest expense to reduce taxable income. The practical of thin capitalization can be used as one strategy of tax avoidance [58]. A company who did tax avoidance had a higher debt to equity ratio [6]. The tax authorities around the world should pay more attention to the practical of intangible assets transfer between groups of companies that located in different tax jurisdiction [33], [34]. [36] claims that about half of the differences in the profitability of US multinationals between high tax jurisdictions and low tax jurisdictions are caused by the transfer of intangible assets such as intellectual and additional capital through reallocation of debt.

Since 1983 Indonesia has started to make the regulation about anti-tax avoidance, it is seen in the article 18 of Laws No 7, 1893 about the Income Tax, up to the latest regulation on PMK-169/PMK. 010/2015 about The Determination of Comparative Amount between Companies' Debt and Capital in order to the Tax Income Calculation. However, there are still many companies in Indonesia, especially Foreign Direct Investment (FDI) which do not hesitate to do the tax avoidance. This is because the process of examination about tax avoidance, for example transfer pricing, is still complicated and takes quite a long time. [50] has proved this phenomenon from the previous study. He states that the percentage of transfer pricing examination to the Foreign Direct Investment only reaches less than $3 \%$ and it is not meet the proportion of the Taxpayer with the Number of Tax Inspector owned by the Directorate General of
Taxes which is only $0.014 \%, 4,552$ tax inspectors versus 33,336,122. (DGT Annual Report, 2015).

Based on those explanations and facts above, the researcher is interested to make a research entitles "The Influence of Income Shifting Incentives towards The Utilization of Tax Haven Country (A case study on the companies listed in the Indonesian Stock Exchange)". It is a replication from the journal done by [71]. This study also continues the research done by [29] which examines the effect of profit transfer instruments (MULTY, TPRICE, TCAP, INTANG) on the utilization of operations in tax haven country with samples of multinational companies listed in Indonesia Stock Exchange especially in manufacturing.

From the explanations above, the variables which are going to be examined to the utilization of tax haven country are multinationality, transfer pricing, thin capitalization, and intangible assets. Therefore, the researcher come with the following hypotheses:

$\mathrm{H} 1=$ Multinationality has a positive significant effect to the utilization of tax haven country

$\mathrm{H} 2=$ Transfer Pricing has a positive significant effect to the utilization of tax haven country.

H3 = Thin Capitalization has a positive significant effect to the utilization of tax haven country

$\mathrm{H} 4$ = Intangible Assets has a positive significant effect to the utilization of tax haven country

H5 = Companies in the Agricultural industry sectors have Multinationality, Transfer Pricing, Thin Capitalization, and Intangible Assets which simultaneously has significant influence to the utilization of Tax Haven Country.

H6 = Companies in the Mining industry sectors have Multinationality, Transfer Pricing, Thin Capitalization, and Intangible Assets which simultaneously has significant influence to the utilization of Tax Haven Country.

$\mathrm{H} 7$ = Companies in the basic and chemicals industry sectors have Multinationality, Transfer Pricing, Thin Capitalization, and Intangible Assets which simultaneously has significant influence to the utilization of Tax Haven Country.

H8 = Companies in the miscellaneous industry sectors have Multinationality, Transfer Pricing, Thin Capitalization, and Intangible Assets which simultaneously has significant influence to the utilization of Tax Haven Country.

H9 = Companies in the consumer goods sectors have Multinationality, Transfer Pricing, Thin Capitalization, and Intangible Assets 
which simultaneously has significant influence to the utilization of Tax Haven Country.

$\mathrm{H} 10=$ Companies in the property, real estate, and building construction sectors have Multinationality, Transfer Pricing, Thin Capitalization, and Intangible Assets which simultaneously has significant influence to the utilization of Tax Haven Country.

$\mathrm{H} 11=$ Companies in the infrastructure, utilities, and transportation sectors have Multinationality, Transfer Pricing, Thin Capitalization, and Intangible Assets which simultaneously has significant influence to the utilization of Tax Haven Country.

$\mathrm{H} 12=$ Companies in the trade, service, and investment sectors have Multinationality, Transfer Pricing, Thin Capitalization, and Intangible Assets which simultaneously has significant influence to the utilization of Tax Haven Country.

\section{RESEARCH METHODOLOGY}

In this research, the object of research to be taken is secondary data obtained from the Indonesian stock exchange (IDX) website on www.idx.co. id, Indonesian capital market directory (ICMD), Jakarta stock industrial classification (JASICA), and from other sources relevant to the study. Period of observation conducted for the period of 2012 until 2016. The type of data used is panel data, which will be processed and analysed by using multiple linear regression analysis model. The type of regression used in this study is logistic regression, because the dependent variable is the dummy variable (0 and 1$)$ which is the categorical (non-metric) variable.

The sampling is done by purposive sampling (judgment sampling) which is part of non-probability sampling method. Sample selection is done based on predetermined criteria, that is by eliminating companies engaged in finance and insurance. The main research model in this study is:

THAVit $=a_{i t}+\beta_{1}$ MULTI $_{i t}+\beta_{2}$ TPRICE $_{i t}+\beta_{3}$ $T C A P_{i t}+\beta_{4} I N T A N G_{i t}+\beta_{5}$ SIZE $_{i t}+\beta_{6} C F O_{i t}+\beta_{7}$ $N O L_{i t}+\beta_{8} R O A_{i t}+\beta_{9} L E V_{i t}+\beta_{10-16} I_{N D S E C}+\beta_{17}$ ${ }_{20} Y E A R_{i t}+\varepsilon_{i t}$

Keterangan:

THAVit = The utilization of Tax Haven Country in a company (i) on the year (t)

MULTI $_{i t}=$ Multinationalism in a company (i) on the year $(\mathrm{t})$

TPRICE $_{\text {it }}=$ Transfer Pricing in a company (i) on the year ( $\mathrm{t}$ )

$\mathrm{TCAP}_{\text {it }}=$ Thin Capitalization in a company (i) on the year (t)
$\mathrm{INTANG}_{\mathrm{it}}=$ Total intangible assets scaled by total assets in a company (i) on the year (t)

SIZE $_{\text {it }} \quad=$ The size of a company (i) on the year (t), measured by natural logarithm of the total assets in a company (i) on the year $(\mathrm{t})$

$\mathrm{CFO}_{\text {it }}=$ Cash flow from operation, scaled by total assets in a company (i) on the year $(\mathrm{t})$

NOLit = Dummy variable in a company (i) on the year ( $\mathrm{t})$, categorized by 1 if net operating loss compensate to the next year, and 0 if in the reverse

ROA $_{\text {it }}=$ Profit before taxes scaled by total assets in a company (i) on the year (t)

$\mathrm{LEV}_{\text {it }} \quad=$ Long term debts scaled by total assets Nilai Hutang Jangka Panjang in a company (i) on the year (t)

INDSECit $=$ Dummy variable in a company (i) on the year (t), categorized by 1 if the company is part of 2 digits group in JASICA, and 0 if it is in reverse

YEAR $_{\text {it }}=$ Dummy variable in a company (i) on the year ( $\mathrm{t})$, categorized by 1 if the company is in the specified year, and 0 if it is in reverse

$\varepsilon_{\mathrm{it}}=$ Error in a company (i) on the year $(\mathrm{t})$

\section{RESULTS AND DISCUSSION}

\section{Descriptive Statistics}

There are nine types of industrial sectors listed in Jakarta Stock Industrial Classification (Jasica) Index, which are: 1) Agriculture, 2) Basic Industry and Chemicals, 3) Consumer Goods Industry, 4) Infrastructure, Utilities and Transportation, 5) Mining, 6) Miscellaneous Industry, 7) Property, Real Estate and Building Construction, 8) Trade, Services \& Investment, and finally 9) Finance (INDSEC8), which is an industrial sector excluded in this study. From the 78 selected samples, it categorized into eight industry sectors. The summary of those eight industry sectors is presented in Table 1.

According to [31], in a study using dummy variables, there must be an exclude group that is used as a reference to compare other variables. The Dummy preference that is eliminated from the industry sector variables is INDSEC9 (Trade, Services \& Investment), and from dummy preference is YEAR in 2016. Table 2 shows descriptive statistics for dependent variables (THAV1 until THAV9), independent variables (MULTI, TPRICE, TCAP and INTANG) and control variables (SIZE, CFO, ZERO, ROA and LEV). The THAV1 has a mean of 0.254 , indicates 
that approximately $25.4 \%$ of the samples has at least one subsidiary established in the OECD tax haven countries (2006). THAV2 has a mean of 0.167 , which means $16.7 \%$ of the samples, in agriculture sector, have at least one subsidiary established in the OECD tax haven countries (2006). THAV3 has a mean of 0.325 , which means that $32.5 \%$ of the sample companies of basic and chemicals industries have at least one subsidiary established in the OECD tax haven countries (2006). THAV4 has mean 0,267, THAV5 has mean 0,125 , THAV6 has mean 0,200, THAV7 has mean 0,333 , THAV8 has mean 0,271, and last THAV9 has mean 0,280. For the independent variables, MULTI, TPRICE, TCAP and INTANG have mean respectively $0.244,0.731,0.866$ and 0.019 . The mean, median and range of each control variable are also reported in Table 2. INDSEC and YEAR variables do not have a prediction mark, according to [71]

\section{The Results of Correlation and Multicollinea- rity Tests}

The 10th assumption of the classical linear regression model states that there is no high or perfect multicollinearity between independent variables [31]. From the overall correlation test results shows that there is no correlation between independent variables that are higher than 0.90 . This can be seen from the results of the correlation test shown in Table 3. Thus, it can be concluded that there is no multicollinearity among independent variables.

In addition to the correlation matrix, this study examined the presence of multicollinearity by using Tolerance and Variance Inflation Factor (VIF) values. Figures commonly used to indicate the presence of multicollinearity are Tolerance $<0.10$ or VIF $>10$. The result confirmed none of the tolerances below 0.10 and VIF exceeded 10 for all explanatory variables. Therefore, there was no multicollinearity problem in this study. Table 2 shows descriptive statistics of samples to be used in this research model.

Table 2 shows descriptive statistics for the dependent variable (THAV1-THAV9), independent variables (MULTI, TPRICE, TCAP and INTANG) and control variables (SIZE, CFO, ZERO, ROA and LEV). The THAV1 dependent variable has a mean or average of 0.254 , indicating that approximately $25.4 \%$ of the sample of all firms has at least one subsidiary established in tax haven countries in OECD (2006). THAV2 has a mean of 0.167 , which means $16.7 \%$ of the sample agriculture companies have at least one subsidiary established in tax haven countries in OECD (2006). THAV3 has a mean of 0.325 , which means that $32.5 \%$ of the sample companies of basic industry and chemicals have at least one subsidiary established in tax haven countries in OECD (2006). THAV4 has a mean of 0.267 ; THAV5 has a mean of 0.125 ; THAV6 has mean of 0,200 ; THAV7 has a mean of 0.333; THAV8 has a mean of 0.271 ; and the last THAV9 has a mean of 0.280. For the independent variables, MULTI, TPRICE, TCAP and INTANG have mean respectively $0.244,0.731,0.866$ and 0.019 . The mean, median and range of each control variable are also reported at 2, except for INDSEC and YEAR which have no predictive signs according to [71].

Table 1. The Categories of Sample Based on the Sector of Industries

\begin{tabular}{|c|c|c|c|}
\hline Industrial Sectors & $\begin{array}{l}\text { Number } \\
\text { of Firms }\end{array}$ & $\begin{array}{l}\text { Percen- } \\
\text { tages (\%) }\end{array}$ & $\begin{array}{l}\text { Dependent } \\
\text { Variables }\end{array}$ \\
\hline Agriculture (INDSEC1) & 6 & 7,68 & THAV2 \\
\hline Mining (INDSEC2) & 8 & 10,26 & THAV3 \\
\hline $\begin{array}{l}\text { Basic Industry and } \\
\text { Chemicals (INDSEC3) }\end{array}$ & 15 & 19,23 & THAV4 \\
\hline $\begin{array}{l}\text { Miscellaneous Industry } \\
\text { (INDSEC4) }\end{array}$ & 8 & 10,26 & THAV5 \\
\hline $\begin{array}{l}\text { Consumer Goods } \\
\text { Industry (INDSEC5) }\end{array}$ & 8 & 10,26 & THAV6 \\
\hline $\begin{array}{l}\text { Property, Real Estate and } \\
\text { Building Construction } \\
\text { (INDSEC6) }\end{array}$ & 9 & 11,54 & THAV7 \\
\hline $\begin{array}{l}\text { Infrastructure, Utilities } \\
\text { and Transportation } \\
\text { (INDSEC7) }\end{array}$ & 14 & 17,95 & THAV8 \\
\hline $\begin{array}{l}\text { Trade, Services \& } \\
\text { Investment (INDSEC9) }\end{array}$ & 10 & 12,82 & THAV9 \\
\hline Total & 78 & 100 & \\
\hline
\end{tabular}

\section{Regression and Hypothesis Results}

The summary of the overall regression results is presented in Table 4 . The summary presents the estimated value of the coefficient and the probability value of individual parameters from the regression test (Test Statistic t), as well as the significant value of the THAV1 - THAV9 from Logistic Regression Test. Note that p-values are one-tailed for hypotheses that have predicted directions and two-tailed for other hypotheses. The coefficients for industry sector variables and year effects are not reported to be more concise [71]. 
Tabel 2. Descriptive Statistic of Variables

\begin{tabular}{l|c|c|c|c|c}
\hline Variabel & Mean & Median & Max. & Min. & Std. Dev. \\
\hline THAV1 & 0,254 & 0,000 & 1,000 & 0,000 & 0,436 \\
\hline THAV2 & 0,167 & 0,000 & 1,000 & 0,000 & 0,379 \\
\hline THAV3 & 0,325 & 0,000 & 1,000 & 0,000 & 0,474 \\
\hline THAV4 & 0,267 & 0,000 & 1,000 & 0,000 & 0,445 \\
\hline THAV5 & 0,125 & 0,000 & 1,000 & 0,000 & 0,335 \\
\hline THAV6 & 0,200 & 0,000 & 1,000 & 0,000 & 0,405 \\
\hline THAV7 & 0,333 & 0,000 & 1,000 & 0,000 & 0,477 \\
\hline THAV8 & 0,271 & 0,000 & 1,000 & 0,000 & 0,448 \\
\hline MHAV9 & 0,280 & 0,000 & 1,000 & 0,000 & 0,454 \\
\hline TPRICE & 0,244 & 0,200 & 1,000 & 0,000 & 0,243 \\
\hline TCAP & 0,731 & 1,000 & 1,000 & 0,000 & 0,444 \\
\hline INTANG & 0,019 & 0,735 & 16,198 & 0,012 & 1,212 \\
\hline SIZE & 20,819 & 0,001 & 0,233 & 0,000 & 0,042 \\
\hline CFO & 0,073 & 19,848 & 30,308 & 11,524 & 4,797 \\
\hline NOL & 0,282 & 0,064 & 0,394 & $-0,331$ & 0,088 \\
\hline ROA & 0,055 & 0,000 & 1,000 & 0,000 & 0,451 \\
\hline LEV & 0,227 & 0,195 & 1,690 & $-0,846$ & 0,151 \\
\hline SOE & 1,464 & 0,000 & 0,252 \\
\hline
\end{tabular}

Source: Authors' Compilation from Statistical Data Processing

Tabel 3. Correlation and Multicollinearity Tests

\begin{tabular}{|c|c|c|c|c|c|c|c|c|c|c|}
\hline Variables & THAV1 & MULTI & TPRICE & TCAP & INTANG & SIZE & CFO & NOL & ROA & LEV \\
\hline THAV1 & 1,000 & & & & & & & & & \\
\hline MULTI & $-0,168$ & 1,000 & & & & & & & & \\
\hline TPRICE & 0,062 & $-0,061$ & 1,000 & & & & & & & \\
\hline TCAP & 0,198 & 0,021 & 0,067 & 1,000 & & & & & & \\
\hline INTANG & 0,258 & $-0,088$ & 0,020 & $-0,046$ & 1,000 & & & & & \\
\hline SIZE & $-0,174$ & $-0,015$ & $-0,035$ & 0,055 & $-0,025$ & 1,000 & & & & \\
\hline $\mathrm{CFO}$ & $-0,180$ & 0,021 & 0,039 & $-0,134$ & $-0,012$ & $-0,160$ & 1,000 & & & \\
\hline NOL & 0,080 & $-0,044$ & 0,059 & 0,007 & 0,010 & $-0,105$ & $-0,048$ & 1,000 & & \\
\hline $\mathrm{ROA}$ & $-0,150$ & $-0,044$ & 0,066 & $-0,162$ & 0,023 & $-0,057$ & 0,415 & $-0,047$ & 1,000 & \\
\hline LEV & 0,154 & 0,041 & 0,042 & 0,275 & 0,074 & $-0,127$ & $-0,148$ & 0,039 & $-0,077$ & 1,000 \\
\hline
\end{tabular}

Source: Authors' Compilation from Statistical Data Processing

Tabel 4. Summary of Regression Results

\begin{tabular}{|c|c|c|c|c|c|c|c|c|c|c|c|}
\hline Variabel & $\begin{array}{c}\text { Perkiraan } \\
\text { Tanda }\end{array}$ & & THAV1 & THAV2 & THAV3 & THAV4 & THAV5 & THAV6 & THAV7 & THAV8 & THAV9 \\
\hline \multirow[t]{2}{*}{ MULTI } & & Koef & $-2,586$ & $-332,516$ & 254,256 & 424,223 & N/A & $-618,995$ & $-92,529$ & 1,884 & $-498,951$ \\
\hline & + & Sig. & 0,002 & 0,500 & 0,499 & 0,490 & N/A & 0,494 & 0,500 & 0,216 & 0,495 \\
\hline \multirow[t]{2}{*}{ TPRICE } & & Koef & 0,386 & 183,496 & 77,422 & $-172,969$ & N/A & $-80,070$ & $-35,843$ & $-1,325$ & 19,570 \\
\hline & + & Sig. & 0,137 & 0,500 & 0,500 & 0,490 & N/A & 0,496 & 0,499 & 0,169 & 0,500 \\
\hline \multirow[t]{2}{*}{ TCAP } & & Koef & 1,098 & $-24,911$ & 8,105 & $-451,827$ & N/A & $-2086,924$ & 34,204 & 8,416 & $-204,277$ \\
\hline & + & Sig. & 0,009 & 0,500 & 0,500 & 0,496 & N/A & 0,491 & 0,499 & 0,007 & 0,495 \\
\hline \multirow[t]{2}{*}{ INTANG } & & Koef & 18,532 & $-188,325$ & 3340,657 & 11807,377 & N/A & $-608,395$ & 176,403 & 18,583 & 477,436 \\
\hline & + & Sig. & 0,000 & 0,500 & 0,500 & 0,494 & N/A & 0,498 & 0,500 & 0,007 & 0,497 \\
\hline \multirow[t]{2}{*}{ SIZE } & & Koef & $-0,166$ & 13,785 & 6,659 & $-101,045$ & N/A & $-47,044$ & $-14,588$ & $-0,326$ & 4,594 \\
\hline & + & Sig. & 0,000 & 0,500 & 0,500 & 0,490 & N/A & 0,492 & 0,498 & 0,081 & 0,497 \\
\hline \multirow[t]{2}{*}{ CFO } & & Koef & $-4,795$ & 242,817 & 100,660 & $-599,125$ & N/A & $-1729,487$ & $-211,059$ & $-23,790$ & $-506,958$ \\
\hline & + & Sig. & 0,007 & 0,500 & 0,500 & 0,495 & N/A & 0,495 & 0,500 & 0,007 & 0,496 \\
\hline \multirow[t]{2}{*}{ NOL } & & Koef & 0,031 & 19,163 & 61,857 & 25,474 & N/A & 26,743 & $-16,691$ & 0,707 & 9,807 \\
\hline & + & Sig. & 0,461 & 0,500 & 0,500 & 0,500 & N/A & 0,499 & 0,499 & 0,317 & 0,500 \\
\hline \multirow[t]{2}{*}{ ROA } & & Koef & $-2,029$ & $-161,804$ & $-76,796$ & 584,161 & N/A & $-916,484$ & 55,613 & $-7,828$ & $-58,182$ \\
\hline & + & Sig. & 0,052 & 0,500 & 0,500 & 0,498 & N/A & 0,498 & 0,500 & 0,039 & 0,498 \\
\hline \multirow[t]{2}{*}{ LEV } & & Koef & $-0,226$ & $-226,209$ & $-425,347$ & 1272,779 & N/A & 2991,477 & $-91,940$ & $-9,424$ & $-484,736$ \\
\hline & + & Sig. & 0,394 & 0,500 & 0,500 & 0,487 & N/A & 0,491 & 0,500 & 0,013 & 0,496 \\
\hline INDSEC & ? & & Yes & No & No & No & No & No & No & No & No \\
\hline YEAR & $?$ & & Yes & Yes & Yes & Yes & Yes & Yes & Yes & Yes & Yes \\
\hline
\end{tabular}

Source: Authors' Compilation from Statistical Data Processing 
In order to test the research hypothesis, the dependent variable of THAV1 has been chosen as the main model. Meanwhile, the dependent variable THAV2 through THAV9 are the additional analysis which aims to test the research hypothesis based on the grouping of industry sector.

H1: Multinationalism has a significant positive effect on the utilization of tax haven countries

Based on the output of the regression results in Table 4, the Multinationality variable has a negative sign and Sig. 0.002 (significant at alpha 0.05). Thus, it can be concluded that the first research hypothesis $\mathrm{H} 1$ is rejected. It explains that multinationality variables negatively affect the utilization of operations in tax haven countries. The result is in contrast to the researches of [71] and [29], in which both resulted in significant positive effects. It is due to the different of the research proxy applied in this study. This study used the MULTI_SUB proxy on robustness test [71].

Basically multinational companies can easily (have a chance) to make income shifting from the country with high tax rates to the country with a low tax rate (tax haven countries). This is in line with the research of [68] which mentioned that multinational companies tend to have greater opportunities and capacities to significantly reduce their corporate taxes compared to pure domestic companies. The negative coefficients in this study caused by several things:

1. Indonesian companies generally only have subsidiaries in Singapore. Although the corporate tax rate is lower than Indonesia's 17\%, Singapore is not included in OECD's list of OECD tax heaven countries in 2006.

2. Indonesian companies that have a subsidiary in a tax-heaven country generally do not have any other subsidiaries abroad, this causes the value of the multinational variable to be 0 (zero).

H2: Transfer-Pricing has no significant positive effect on the utilization of tax haven countries

Based on the output of regression results in Table 4, the TPRICE variable has a positive but not significant sign (p-value 0.137>0.05). So it can be concluded that TPRICE variable has no significant effect to the utilization of operation in tax haven countries. The results of this study differ from the results of research [71], so the second research hypothesis is rejected.
According to [5], and [88], a company not only uses the benefits of tax haven countries for the benefit of transfer pricing and tax avoidance strategies, but also for financial arbitrage to manage their foreign currency cash flow and avoid risk from foreign exchange rates. In addition, transactions of pricing transactions with related parties are generally conducted by Indonesian companies with local subsidiary companies, where there is no difference in tariffs, so that the effect of transfer pricing on the utilization of tax haven countries is not significant.

H3: Thin Capitalization has a significant positive effect on tax haven countries utilization

Based on the output of regression results in Table 4, the TCAP variable has a positive and significant mark ( $p$-value $0.009<0.05$ ). So it can be concluded that TCAP variable has a positive effect on the utilization of operation in tax haven countries. The results of this study are in line with the results of [71]. Thus, the third research hypothesis is accepted.

H4: Intangible Assets have significant positive influence on the utilization of tax haven countries

Based on the output of regression results in Table 4, INTANG has a positive sign, and significant ( $p$-value $0,000<0.05$ ). So it can be concluded that the fourth research hypothesis is accepted. This means that INTANG variable has a significant positive effect on the utilization of operation in tax haven countries. This hypothesis supports the research from [71].

H5-H12: Companies in various sectors observed have Multinationalism, Transfer Pricing, Thin Capitalization, and Intangible Assets which simultaneously significantly influence the utilization of Tax Haven Countries

Based on Table 5, companies in various industrial sectors, namely agriculture (H5), mining (H6), basic and chemicals (H7), miscellaneous (H8), consumer goods (H9), property, real estate, \& building construction H10), infrastructure, utilities \& transportation (H11), and trade, service, \& investment (H12), have a greater chi-square value than the critical chi-square value. In addition, the p-value values of each industry group also show significant value, thus the fifth hypothesis to the twelfth hypothesis (H5 - H12) are acceptable. 
Significance of Income Shifting Incentives toward Utilization of Tax Haven Countrie (THAV2 s.d. THAV9)

1. Simultaneous Significance per Industry Sector Based on Table 5, it is seen that Income Shifting Incentives, which are MULTI, TPRICE, TCAP, and INTANG simultaneously have a significant effect on the utilization of Tax Haven Country for all industry sectors (Sig. <0.05). Since all Income Shifting Incentives simultaneously have a significant effect on the utilization of Tax Haven Country for all industry sectors, then to determine which industry sector has the highest significance level is to compare the chi-square count with the chi-square table. When the chi-square difference with the chisquare table in an industry is found in high numbers, it is the industrial sector that has the most significant Income Shifting Incentives effect on the utilization of Tax Haven Country. Industrial sectors with the highest level of significance are basic industry and chemicals sector with Chi-square or LR statistic 86,987; and the lowest is industrial sector agriculture with Chi-square or LR statistic 27,034.

2. Individual Significance per Industry Sector The results of this study argue that although with a low level of significance, agriculture industry sector more often use tax haven country through all income shifting incentives that exist. All income shifting incentives in the mining industry sector also have a low level of significance to the utilization of tax haven countries. However, this industry sector has MULTI variable, which is the variable that has the greatest influence compared with other variables. This indicates that the mining industry sector is more likely to choose income shifting incentives by establishing a subsidiary in tax haven countries in its efforts to take advantage of tax haven countries.

Tabel 5 Omnibus Test of Model Coefficients THAV2THAV9

\begin{tabular}{lccc}
\hline Variabel & Chi-square & df & Sig. \\
\hline THAV2 & 27,034 & 13 & 0,012 \\
THAV3 & 50,446 & 13 & 0,000 \\
THAV4 & 86,987 & 13 & 0,000 \\
THAV5 & 30,142 & 13 & 0,004 \\
THAV6 & 40,032 & 13 & 0,000 \\
THAV7 & 57,286 & 13 & 0,000 \\
THAV8 & 50,112 & 13 & 0,000 \\
THAV9 & 59,295 & 13 & 0,000 \\
\hline
\end{tabular}

Source: Authors' Compilation from Statistical Data Processing

\section{CONCLUSION AND SUGGESTIONS}

\section{Conclusion}

This study aims to determine the effect of Income Shifting Incentives in the form of MULTI, TPRICE, TCAP, and INTANG on the utilization of Tax Haven Country. Based on the results of research and discussion that has been described previously, then Multinationalism (MULTI) has a significant negative impact on tax haven country utilization. This is different from [71], and [29] study. Factors that are considered to provide different results are the selection of proxies used for these variables. Variable Transfer Pricing (TPRICE) has positive but not significant effect on tax haven country utilization. The results of this study differ from the results of research [71] and research [29]. [71] study said that TPRICE has a positive and significant impact on tax haven country utilization; while [29] concluded that TPRICE had a negative and insignificant effect. Thin Capitalization (TCAP) and Intangible Assets (INTANG) variables have a positive and significant impact on tax haven country utilization. This result is in line with research results from [71]. However, the effect of TCAP on the utilization of tax haven country is different from the results of research conducted by [29]. This difference is also indicated due to differences in proxy measurement used.

Based on the additional analysis using observation data that has been grouped into each sector of industry, obtained results indicating that Income Shifting Incentives of MULTI, TPRICE, TCAP, and INTANG simultaneously have a significant effect on the utilization of Tax Haven Country. These results were found in all industries observed. However, the industry sector with the highest level of significance is the basic industry and chemicals sector with Chi-square or LR statistic 86,987 and the significance level of 0,000 $(<0.05)$. This means that companies in the basic and chemical industries sector are more likely to utilize tax haven country with various income shifting incentives, such as multiplying subsidies in tax haven country, transfer pricing, thin capitalization, and intangible assets transfers.

Each industry sector has a different way of utilizing tax haven country. In agriculture industry sector, all income shifting incentives in this research are used to utilize tax haven country. The mining industry sector is more likely to establish a subsidiary in tax haven country in order to utilize tax haven country. Basic and chemicals industry sectors tend to establish subsidiaries in tax haven country and transfer pricing. In the Miscellaneous 
industry sector, it is not known what income shifting incentives are likely to be utilized in utilizing tax haven country due to inadequate observational data. In the consumer goods industry, companies tend to use thin capitalization. In the property, real estate, \& building construction sector, it is found that transfer pricing and thin capitalization are income shifting incentives that tend to be used in tax haven country. Companies in the infrastructure, utilities \& transportation sector tend to use thin capitalization and intangible assets transfers and the industry's last trade sector. Service \& \& investment industries are more likely to increase the number of subsidiaries in tax haven country and use thin capitalization in utilizing the existing facilities in tax haven country.

\section{Suggestions}

Based on the conclusions and limitations of the study, the suggestions drawn up in this study are as follows:

1. Subsequent research can expand the object of research by choosing not only companies that have subsidiaries abroad but also companies that do not have a subsidiary abroad to avoid data that correlates perfectly. In addition, not all companies disclose all of their subsidiaries in the financial statements for materiality reasons [71].

2. Further researches are expected to use other variables that influence tax haven country utilization, such as the interaction between TPRICE and INTANG (TPRICE * INTANG), corporate governance, and withholding taxes according to research conducted by [85]. Subsequent research can also extend the observation data, for example into 7 (seven) or 10 (ten) years, so that the results of research can be more leverage. In addition, further research is expected to use other databases in addition to financial statements published on the Indonesia Stock Exchange, such as internal data owned by the Directorate General of Taxes.

3. The effect of the transfer pricing variable on the utilization of tax haven country has not been in accordance with [71], because this study establishes the company's pricing transfer indicator simply by reading the information contained in the Notes to the Financial Statements which may not be fully disclosed. Therefore further research is expected to use another proxy in measuring the effect of transfer pricing on tax haven country utilization by adding eight different pricing items then scaled to 8 (eight) according to [70].
4. Directorate General of Taxation is expected to review Finance Minister Regulation (PMK) Number 169 / PMK.03 / 2015, because the high debt to equity ratio is a gap for companies. In this study, the observed firms (84 observational data) had a low MAD (Maximum Allowable Debt) ratio, which was below 4: 1 . In an effort to maximize the ratio to $4: 1$, of course, will reduce the corporate tax burden and ultimately result in the decline in potential tax revenue. In addition, it is necessary to improve supervision on companies in the study who have a relatively high MAD ratio (more than 1.000).

5. It is expected that the Directorate of Inspection and Billing, Directorate of Potential, Compliance and Admission (PKP), Tax Intelligence Directorate (IP), International Taxation Directorate (PI), DGT Regional Office of WP Besar and DGT Special Office of Jakarta will focus more on the sector basic industries and chemicals in the preparation of the proposed inspection plan and the potential thematic exploration related to profit shifting incentives.

6. The Directorate General of Tax (DGT), especially the Regional Office of the DGT and DJP Special Office of Jakarta, is expected to increase supervision and inspection related to transfer pricing in agriculture, basic and chemicals, and property, real estate \& building construction. In addition, the DGT is also expected to improve oversight of taxpayer compliance to PMK No. 169 / PMK.03 / 2015, especially in the following industrial sectors: a) agriculture, b) consumer goods, c) property, real estate, \& building construction, d) infrastructure, utilities \& transportation, and e) trade, service, \& investment. DGT can also increase awareness of Taxpayers, in the agriculture, mining, basic and chemicals, and trade, service, \& investment sectors, which have a growing number of subsidiaries in tax haven country. As well as the latter is the DGT can increase supervision of intangible assets transfers in sectors in the agriculture and infrastructure, utilities \& transportation industries.

\section{REFERENCES}

[1] Akamah, H., Hope, O.-K., \& Thomas, W. B. 2014. Tax Havens and Disclosure Aggregation. Working Paper.

[2] Ariyanti, Fiki. 2016. "2000 Perusahaan Asing Gelapkan Pajak Selama 10 Tahun”. Liputan 6. http://bisnis.liputan6.com/read/2469089/ 2000-perusahaan-asing-gelapkan-pajak-selama-10-tahun_(diakses tanggal 10 Maret 2017). 
[3] Baltagi, Badi H. 2005. Econometric Analysis of Panel Data Third Edition. England: John Wiley \& Sons Ltd, The Atrium, Southern Gate.

[4] Bernard, A.B., Jensen, J.B., Schott, P.K., 2006. Transfer Pricing by U.S.-Based Multinational Firms. NBER Working Paper 12493. http://www.nber.org/papers/w12493.

[5] Bartelsman, E. and R. Beetsma (2003), Why pay more? Corporate tax avoidance through transfer pricing in OECD countries. Journal of Public Economics 87, 2225-2252.

[6] Beuselinck, C., Buysschaert, A., \& Deloof, M. 2005. Business groups, taxes and earnings management. Paper prepared for the European Accounting Association.

[7] Blouin, J., Huizinga, H., Laeven, L., \& Nicodeme, G. 2013. Thin capitalization rules and multinational firm capital structure. Working paper. Oxford, U.K.: Oxford University.

[8] Brown, K. B. (2012). A Comparative Look at Regulation of Corporate Tax Avoidance. New York: Springer.

[9] Chen, S., X. Chen, Q. Cheng, and T. Shevlin, 2010. Are family firms more tax aggressive than nonfamily firms? Journal of Financial Economics, 95(1): 41-61.

[10] Coleman, N., \& Bean, E. J. 2006. Tax Haven Abuses: the Enablers, the Tools and Secrecy Minority \& Majority Staff Report Permanent Subcommittee. Office.

[11] Darussalam, Danny Septriadi. 2008. Konsep dan Aplikasi Cross-Border Transfer Pricing untuk Tujuan Perpajakan. Jakarta: PT Dimensi Internasional Tax.

[12] Darussalam, Danny Septriadi, dan B. Bawono Kristiaji. 2013. Transfer pricing: Ide, Strategi, dan Panduan Praktis dalam Perspektif Perpajakan Internasional. Jakarta: Danny Darussalam Tax Center.

[13] Darussalam, Danny. 2009. "Tax Avoidance, Tax Planing, Tax Evasion, dan Anti Avoidance Rule”. Ortax.org. http://www.ortax.org/ $\operatorname{ortax} /$ $/ \mathrm{mod}=$ issue\&page $=$ show\&id=36\&list $=$ $\& q=\& h l m=5$ (diakses tanggal 10 Maret 2017).

[14] Department of the Treasury. 2007. Report to the congress on earnings stripping, transfer pricing and US income tax treaties. Washington, DC: Department of the Treasury (Available at: http://www.treasury.gov/resourcecenter/ tax-policy/Documents/ajca2007.pdf).

[15] Desai, M.A., Foley, C. F., \& Hines, J.R. 2006a. The demand for tax haven operations. Journal of public Economics, 90, 513-531

[16] Desai, M.A., Foley, C. F., \& Hines, J.R. 2006b. Do Tax Haven Divert economic activity? Economics Letters, 90, 21-224

[17] Desai, M., \& Dharmapala, D. 2009. Earnings management, corporate tax shelters, and book-tax alignment. Harvard Business School Finance Working Paper, No. 884812 Cambridge, MA.

[18] Dharmapala, D., \& Hines, J. R. 2009. Which countries become tax havens? Journal of Public Economics, 93(9-10), 1058-1068. http://doi.org/10.1016/j.jpubeco.2009.07.005

[19] Direktorat Jenderal Pajak. Laporan Tahunan Tahun 2015. Jakarta: Direktorat Jenderal Pajak

[20] Direktorat Jenderal Pajak. Peraturan Direktur Jenderal Pajak Nomor PER-43/PJ/2010 jo PER-32/PJ/2011 tentang Penerapan Prinsip Kewajaran Dan Kelaziman Usaha Dalam Transaksi Antara Wajib Pajak Dengan Pihak Yang Mempunyai Hubungan Istimewa

[21] Doggart, Caroline. 2002. Tax Haven and Their Uses. London: Economic Intelligence Unit.

[22] Dyreng, S. D., Hanlon, M., \& Maydew, E. L. 2008. Long-Run Corporate Tax Avoidance. The Accounting Review, 83(1), 61-82. http://doi.org/10.2308/accr.2008.83.1.61

[23] Dyreng, S. D., \& Lindsey, B. P. 2009. Using financial accounting data to examine the effect of foreign operations located in tax havens and other countries on U.S. multinational firms' Tax rates. Journal of Accounting Research, 47(5), 1283-1316. http://doi.org/ 10.1111/j.1475-679X.2009.00346.x

[24] Eden, L., \& Smith, L. M. 2011. The ethics of transfer pricing. Working paper. College Station, TX: Texas A\&M University.

[25] Epstein, B. J., \& Jermakowics, E. K. 2008. Wiley IFRS 2008: Interpretation and application of international financial reporting standards. Hoboken, NJ: John Wiley and Sons.

[26] Field, Andy. 2009. Discovering Statistics Using SPSS Third Edition. London: Sage Puclication Ltd.

[27] Erickson, M., Hanlon, M., \& Maydew, E. L. 2004. How much will firms pay for earnings that do not exist? Evidence of taxes paid on allegedly fraudulent earnings. Accounting Review. http://doi.org/10.2308/accr.2004.79.2.387

[28] Feinschreiber, Robert. 2004. Transfer pricing Method. New Jersey: Wiley and Sons, Inc.

[29] Frandyanto, Satria Agus. 2017. Pengaruh Instrumen Pengalihan Laba Terhadap Pemanfaatan Negara Lindung Pajak (Tax Haven Country). Tangerang Selatan: Politeknik Keuangan Negara-STAN.

[30] Frank, M. M., Lynch, L. J., \& Rego, S. O. 2009. Tax reporting aggressiveness and its relation to aggressive financial reporting. In Accounting Review, 84, pp. 467-496). http:// doi.org/10.2308/accr.2009.84.2.467 
[31] Ghozali, Imam dan Dwi Ratmono. 2013. Aplikasi analisis multivariate dan ekonometrika: teori, konsep dan aplikasi dengan Eviews8. Semarang: Badan Penerbit UNDIP.

[32] Ghozali, Imam. 2016. Aplikasi analisis multivariate dengan program IBM SPSS 23. Semarang: Badan Penerbit UNDIP.

[33] Gravelle, J. G. 2009. Tax Havens: Internationnal Tax Avoidance and Evasion. National Tax Journal, 62(4), 727-753. http://doi.org/ $10.2307 / 41790645$

[34] Gravelle, J. G. 2013. Tax Havens : International Tax Avoidance and Evasion. Congressional Research Service Report for Congress (Available at: http://fas.org/sgp/crs/misc/ R40623.pdf).

[35] Grubert, H., \& Mutti, J. 1991. Taxes, Tarifs and Transfer Pricing in Multinational Corporate Decision Making. The Review of Economics and Statistics, 73(2), 285-293. http://doi. org/10.2307/2109519.

[36] Grubert, H. 2003. Intangible income, intercompany transactions, income shifting and the choice of location. National Tax Journal, $56,221-242$

[37] Gujarati, Damodar N. 2004. Basic econometrics (4th edition). New York: McGraw-Hill Companies.

[38] Gujarati, Damondar N dan Dawn C Porter. 2012. Dasar-Dasar Ekonometrika. Jakarta: Salemba Empat.

[39] Gunadi. 1994. Transfer Pricing Suatu Tujuan Akuntansi, Manajemen dan Pajak. Jakarta: PT Bima Rena Pariwara.

[40] Hanlon, M. (2005). The persistence and pricing of earnings, accruals, and cash flows when firms have large booktax differences. The Accounting Review, 80(1), 137-166.

[41] Harris, D., Morck, R., Slemrod, J., \& Yeung, B. 1993. Income Shifting in U.S. Multinational Corporations. University of Chicago Press. http://doi.org/10.3386/w3924

[42] Hines, J. R., 1996. Tax policy and the activeties of multinational corporations. NBER Working Paper.

[43] Hodge, Margareth. 2013. MPs Publish report on Google's tax avoidance. Commite of Public Account. UK Parliament.

[44] Hoffman, W. H. 1961. The theory of tax planning. The Accounting Review, 36(2), 274281.

[45] Indonesia Stock Exchange - Bursa Efek Indonesia. http://www.idx.co.id/ (diakses tanggal 10 Maret 2017).

[46] Indonesia. Undang-Undang Pajak Penghasilan. Undang-undang No.7/1983 tentang Pajak Penghasilan sebagaimana telah beberapa kali diubah terakhir dengan Undang-Undang No.36/2008.
[47] Indonesia. Undang-Undang Ketentuan Umum dan Tata Cara Perpajakan. Undang-Undang No. 16/2009 tentang Penetapan Peraturan Pemerintah Pengganti Undang-Undang Nomor 5 Tahun 2008 Tentang Perubahan Keempat Atas Undang-Undang Nomor 6 Tahun 1983 Tentang Ketentuan Umum Dan Tata Cara Perpajakan Menjadi UndangUndang.

[48] ICIJ. 2016. "Panama Papers Global Overview". The International Consortium of Investigative Journalists. https://panamapapers. icij.org/20160403-panama-papers-global-overview.html (diakses tanggal 10 Maret 2017).

[49] Inilah Daftar Ribuan Nama Indonesia Di Panama Papers (Alphabetical Order). http:// indocropcircles.wordpress.com/2016/04/06/inilah -ribuan-nama-indonesia-di-panama-papersalphabetical-order/ (diakses tanggal 10 Maret 2017).

[50] Irnowo, Banon Keke, 2016. Analisis Kebutuhan Penerapan Transfer Pricing Risk Assessment di Indonesia. Skripsi. Tangerang Selatan: Politeknik Keuangan Negara-STAN

[51] Jakarta Stock Industrial Classification (Jasica) Index. https://eprints.uny.ac.id/7898/5/ lampiran-08408141022.pdf (diakses tanggal 10 Maret 2017).

[52] Kementerian Keuangan. Peraturan Menteri Keuangan Nomor PMK-169/PMK.010/2015 tentang Penentuan Besarnya Perbandingan Antara Utang Dan Modal Perusahaan Untuk Keperluan Penghitungan Pajak Penghasilan.

[53] Kementerian Keuangan. Peraturan Menteri Keuangan Nomor PMK-213/PMK.003/2016 tentang Dokumen Hubungan Istimewa Terkait Transfer Pricing.

[54] Keraf, Sonny. 1998. Etika Bisnis, Tututan dan relevansinya. Jogjakarta: Kanisius.

[55] Kim, J. B., Li, Y., \& Zhang, L. 2011. Corporate tax avoidance and stock price crash risk: Firm-level analysis. Journal of Financial Economics, 100, 639-662.

[56] Klassen, Lang, \& Wolfson. 1993. Geographic income shifting by multinational corporations in response to tax rate changes. Journal of Accounting Research, 31, 141-173

[57] Klassen, K. J., \& Laplante, S. K. 2012. The Effect of Foreign Reinvestment and Financial Reporting Incentives on Cross-Jurisdictional Income Shifting. Contemporary Accounting Research, 29(3), 928-955. http://doi.org/ 10.1111/ j.1911-3846.2011.01136.x

[58] Lietz, Gerrit M. 2013. Determinants and Consequences of Corporate Tax Avoidance. Working Paper University of Münster. http://dx.doi. org/10.2139/ssrn.2363868. 
[59] Modigliani, F., \& Miller, M. 1963. Corporate Income Taxes and the Cost of Capital: A Correction. American Economic Review, 53, 443-443.

[60] Nachrowi, Nachrowi Djalal dan Hardius Usman. 2006. Pendekatan populer dan praktis ekonometrika untuk analisis ekonomi dan keuangan. Jakarta: Lembaga Penerbit FEUI.

[61] Newberry, K.Y., Dhaliwal, D.S., 2001. Cross jurisdictional income shifting by U.S. multinationals: evidence from international bond offerings. Journal of Accounting Research 39(3), 643-662.

[62] OECD. 2012. Dealing Effectively with the Challenges of Transfer pricing, Paris: OECD Publishing.

[63] OECD. 2013. Public Consultation: Draft Handbook on Transfer pricing Risk Assessment. Paris: OECD Publishing

[64] OECD. 2013. Public Consultation White Paper on Transfer pricing Documentation. Paris: OECD Publishing

[65] OECD. 2006. The OECDs Project on Harmful Tax Practices: 2006 Update on Progress in Member Countries. Washington DC: OECD.

[66] OECD.2009. Countering Offshore Tax Evasion. Washington DC: OECD

[67] Omar, N., \& Zolkaflil, S. 2015. Profit Shifting and Earnings Management through Tax Haven Subsidiaries: An Exploratory Analysis of Multinational Companies. Procedia Economics and Finance, 28(April), 53-58. http://doi. org/10.1016/S2212-5671(15)01081-3

[68] Rego, S. O. 2003. Tax-Avoidance Activities of U.S. Multinational Corporations. Contemporary Accounting Research, 20(4), 805-833. http://doi.org/10.1506/VANN-B7UB-GMFA9E6W

[69] Richardson, G., Hanlon, D., Nethercott, L., 1998. Thin capitalization: an Anglo-American comparison. The International Tax Journal 24(2), 36-66.

[70] Richardson, G., Taylor, G., \& Lanis, R., 2013. Determinants of Transfer Pricing Aggressiveness, Journal of Contemporary Accounting \& Economics 9, 136-150.

[71] Richardson, G., and Taylor, G. 2015. Income Shifting Incentives and Tax Haven Utilization: Evidence from Multinational U.S. Firms. International Journal of Accounting, 50(4), 458-485. http://doi.org/10.1016/j.intacc. 2015.10.001

[72] Rohatgi, Roy. 2007. Basic International Taxation: vol. Two: Practice. Taxmann.

[73] Sekaran, Uma. 2006. Metodologi Penelitian untuk Bisnis: Buku 1. Jakarta: Salemba Empat.
[74] 2006. Metodologi Penelitian untuk Bisnis: Buku 2. Jakarta: Salemba Empat.

[75] Shevlin, T. 2007. The Future of Tax Research: From an Accounting Professor's Perspective. The Journal of the American Taxation Association, 29(2), 87-93.

[76] Slamet, Indrayagus. 2007. Tax Planning, Tax Avoidance, dan Tax Evasion di Mata Perpajakan Indonesia. Inside Tax Edisi September. Hal 8

[77] Slemrod, J., 2001. A general model of the behaviour response to taxation. International Tax and Public Finance 8(2), 119-128.

[78] Statistik Keuangan Indonesia. Bank Indonesia. http:/www.bi.go.id/en/statistik/seki/terkini/keuangan-pemerintah/Contents/ Default.aspx (diakses tanggal 10 Maret 2017).

[79] Stewart, J.C., 1977. Multinational companies and transfer pricing. Journal of Business Finance and Accounting, 4(3), 353-371.

[80] Suandy, Erly. 2008. Perencanaan Pajak. (Edisi ke-4). Jakarta: Salemba Empat.

[81] Sugiyono. 2010. Metode Penelitian Kuantitatif, kualitatif dan $R \& D$. Bandung: Alfabeta.

[82] Sugiyono. 2014. Metode Penelitian Bisnis. Bandung: Alfabeta.

[83] Sugiyono. 2016. Metode Penelitian Kuantitatif, kualitatif dan $R \& D$. Bandung: Alfabeta.

[84] Taylor, G., \&. Richardson, G., \&. 2013. The determinants of thiny capitalized tax avoidance structures: Evidence from Australian firms. International Journal of Accounting, Auditing and Taxation 22(2013), 12-25. http://dx.doi.org/10.1016/j.intaccaudtax.2013.0 2.005

[85] Taylor, G., Richardson, G., \& Taplin, R., 2014. Determinants of tax haven utilization: evidence from Australian Firm. Journal of Accounting and Finance. doi: 10.1111/acfi. 12064.

[86] Tim Dosen Ekonometrika. 2015. Buku Pedoman Praktikum Ekonometrika. Malang: Universitas Brawijaya.

[87] United Nations. 2013. Practical Manual on Transfer Pricing for Developing Countries. New York: United Nations.

[88] Usmen, Nilufer. 2012. Transfer Prices: A Financial Perspective. Journal of International Financial Management \& Accounting 23(1). DOI: 10.1111/j.1467-646X.2011.01052.x

[89] Webber, S. 2010. Thin capitalization and interest deduction regulations. Copenhagen research group on international taxation. Corit discussion paper, No. 8, (Available from: http://corit-academic.org/wp-content/uploads/ 2011/12/CORIT-8-Thin-Capitalization-andEarnings-Stripping-Regulations-2-1.pdf).

[90] Wilkie, P., 1988. Corporate average effective tax rates and inferences about relative tax preferences. Journal of the American Taxation Association 10 (2), 75-88. 
[91] Winarno, Wing Wahyu. 2015. Analisis Ekonometrika dan Statistika dengan Eviews. Buku Edisi 4. Yogyajkarta: UPP STIM YKPN.

[92] Widarjono, Agus. 2013. Ekonometrika: Pengantar dan Aplikasinya. Yogyakarta: Ekonisia FE UII.
[93] Widarjono, Agus. 2010. Analisis Multivariat Terapan Dengan Program SPSS, AMOS, dan SMARTPLS. Yogyakarta: UPP STIM YKPN.

[94] Yamin, Sofyan dan Heri Kurniawan. 2014. SPSS Complete: Teknik Analisis Statistik Terlengkap SPSS (Edisi 2). Jakarta: Salemba Empat. 